\title{
Anion sensitivity of motility and step-down photophobic responses of Euglena gracilis
}

\author{
Mike J. Doughty and Bodo Diehn* \\ Stanford University Medical Center, Division of Ophthalmology S030, Stanford, CA 94305, USA
}

\begin{abstract}
The motility and step-down photophobic responses of Euglena are influenced by inorganic and organic anions. Persistent motility (with $\mathrm{Ca}^{2+}, \mathrm{Mg}^{2+}$ and $\mathrm{K}^{+}$present) is supported with chloride or sulfate but not with acetate, nitrate or propionate as the only added anions. Cells in media containing acetate displayed a cell aggregation (clumping) behavior that was both red light sensitive and, under some conditions, was accompanied by suppression of the step-down photophobic response. Addition of sodium salts $\left(\mathrm{Cl}^{-}, \mathrm{SO}_{4}^{2-}\right.$, acetate or propionate) to cells in $\mathrm{Cl}^{-}$or $\mathrm{SO}_{4}^{2-}$ based media had differential effects on the duration of the step-down photophobic responses induced by blue light removal: anions alter the response. In addition, cells in all $\mathrm{Cl}^{-}$containing media showed constant photophobic response duration following repeated stimulation. Cells in some $\mathrm{SO}_{4}{ }^{2-}$ containing media, however, showed response summation to repeated stimulation. This latter effect was reversible and was overcome by the addition of chloride anions.
\end{abstract}

Key words: Photosensory - Anions, flagellated - Algae Motility - E. gracilis

Euglena can respond to a reduction in incident light intensity by showing a step-down photophobic response. The cells then resume that swimming behavior observed prior to the reduction in light intensity (Doughty and Diehn 1979). The response magnitude is dependent on both the light intensity reduction $(\Delta \mathrm{I})$ as well as the intensity (I: fluence rate) and duration of the light imposed upon on the cells prior to that reduction required to elict the response (Doughty and Diehn 1979; Creutz et al. 1978; Shimmen 1981). Photic stimulusresponse relationships in Euglena have been interpreted as reflecting the photochemical reactions in the chromophore system (Diehn 1973; Creutz et al. 1978; Shimmen 1981). However, the expression of the step-down photophobic response has been found to be influenced by the ionic composition of the extracellular medium (Doughty and Diehn 1983) and the duration of the response has been found to be altered by certain cations (Colombetti et al. 1982). Such alterations in the step-down photophobic response are not readily attributable to the primary photoprocesses themselves but

\footnotetext{
* Present address: Institute of Science and Technology, University of Michigan, Ann Arbor, MI 48109, USA

Offprint requests to: M. J. Doughty
}

rather reflect steps in the transduction sequence between light perception and flagellar activity change. The relative effects of cations have been found to be interdependent (Doughty et al. 1980; Doughty and Diehn 1983). These studies have provided evidence as to the principal cation species involved in the transduction and locomotory processes. This report concerns the anion sensitivity of motility and the step-down photophobic response of Euglena.

\section{Materials and methods}

Euglena gracilis strain $Z$, was cultured on either Bloomington medium (Starr 1964) or glutamate-malatemetals 47 medium (Greenblatt and Schiff 1959) under constant cool white fluorescent light of $3 \mathrm{~W} \cdot \mathrm{m}^{-2}$ at $25^{\circ} \mathrm{C}$. Mid- to late-logarithmic cultures $\left(1-2 \cdot 10^{6} \mathrm{cells} / \mathrm{ml}\right)$ were harvested by centrifugation $(121 \times \mathrm{g} / 45 \mathrm{~s})$, washed by centrifugation and resuspended $\left(1-2 \cdot 10^{5}\right.$ cells $\left./ \mathrm{ml}\right)$ in a buffered solution of $\mathrm{pH}$ 7.1. All solutions contained $0.5 \mathrm{mM}$ $\mathrm{Ca}^{2+}, 0.125 \mathrm{mM} \mathrm{Mg}^{2+}$ and 1 or $5 \mathrm{mM} \mathrm{K}^{+}$. Buffering was achieved either through use of Tris base and appropriate acids or through a combination of Hepes-Pipes buffers and $\mathrm{NaOH}$ or $\mathrm{KOH}$. The anionic species were chloride, sulfate, acetate, nitrate or propionate added as suitabie salts and acids. Cells were transferred to dim red light $\left(70 \mathrm{~mW} \cdot \mathrm{m}^{-2}\right.$, $>650 \mathrm{~nm})$ at $25^{\circ} \mathrm{C}$ and adapted, for the time periods specified, to the various buffer-salt solutions. Step-down photophobic responses were evaluated under $1-2 \mathrm{~W} \cdot \mathrm{m}^{-2}$ red light (>650 nm) at $19-23^{\circ} \mathrm{C}$ with the cells being first exposed for $60 \mathrm{~s}$ to blue light $(466 \mathrm{~nm}, 10 \mathrm{~nm}$ band pass interference filter) at a fluence rate of $40 \mathrm{~mW} \cdot \mathrm{m}^{-2}$. In some cases this blue light illumination period was for 6 or $8 \mathrm{~min}$. This actinic illumination was then removed and the step-down photophobic response evaluated by microscope analysis (Doughty and Diehn 1979).

\section{Results}

We have previously studied the step-down photophobic response and motility of Euglena in a series of buffer-salt solutions in which chloride anion was the only added anion. There is, however, a dependence of cell behavior on anions. Complete anion substitution is possible only on a limited basis and we have found that only chloride and sulfate were successful in preserving the motility of Euglena for $24 \mathrm{~h}$ under dim red light at $25^{\circ} \mathrm{C}$. Motility is poor or rapidly lost (ca. $50 \%$ immotile in $2-3 \mathrm{~h}$ ) if the anion was acetate, 


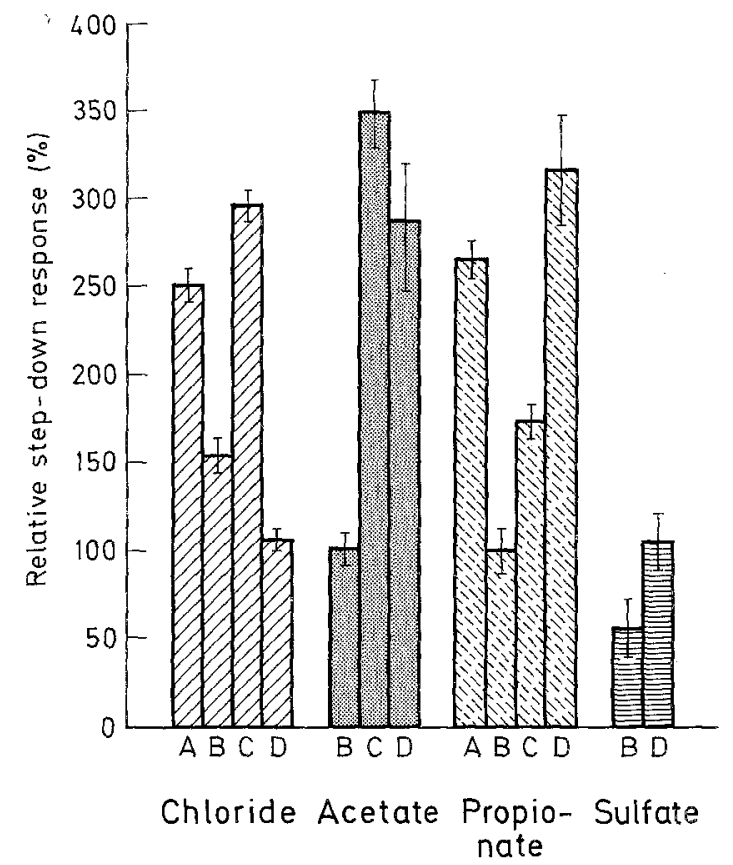

Fig. 1. Relative effects of $\mathrm{Na}^{+}$and anions on the duration of stepdown photophobic responses. Cells adapted to buffers at $\mathrm{pH} 7.1$ containing $\mathrm{Ca}^{2+}$ and $\mathrm{Mg}^{2+}$ (see methods) with either chloride ( $A$, $B)$ or sulfate $(C, D)$ anions throughout and which also contain either $1 \mathrm{mM} \mathrm{K}^{+}(A, C)$ or $5 \mathrm{mM} \mathrm{K} \mathrm{K}^{+}(B, D)$. Responses (total response duration) expressed as relative to that response magnitude observed in the absence of $\mathrm{Na}^{+}$salt addition. The $100 \%$ response values were $A: 20.6 \pm 1.5 \mathrm{~s} ; B: 30.8 \pm 0.7 \mathrm{~s} ; C: 9.8 \pm 0.8 \mathrm{~s}$ and $D: 39.0 \pm 2.0 \mathrm{~s}$. All salts added at $8 \mathrm{mM}$ final concentration

propionate or nitrate. These anion effects were observed with cells grown in either culture medium.

Celis in buffers containing $\mathrm{Cl}^{-}$initially show poor stepdown photophobic responses despite strong motility, but the responses increase progressively and attain a stable magnitude after $8-12 \mathrm{~h}$. The response magnitude is dependent upon the $\mathrm{K}^{+}$concentration (Doughty and Diehn 1983). Thus for example, in the present series of experiments, step-down photophobic response durations of $20.6 \pm 1.5 \mathrm{~s}$ $(n=7, \pm \mathrm{SEM})$ and $30.8 \pm 0.7 \mathrm{~s}(n=10)$ were observed for cells in media with 1 or $5 \mathrm{mM} \mathrm{K}{ }^{+}$, respectively. Cells in sulfate anion buffers also initially showed weak step-down photophobic responses. If $1 \mathrm{mM} \mathrm{K}{ }^{+}$are present, the response magnitude remains small even after $15-20 \mathrm{~h}(6-$ $10 \mathrm{~s}$ compared to $17-24 \mathrm{~s}$ ). If $5 \mathrm{mM} \mathrm{K}^{+}$are present, the response magnitude increases rapidly and by $16-18 \mathrm{~h}$ is of the same magnitude as that for cells in the chloride containing buffers ( $32-40 \mathrm{~s}$ compared to $27-34 \mathrm{~s})$. In all four of these solutions, cells always showed strong motility of the characteristic straight path type with a low frequency of directional changes. In response to a reduction in blue light intensity, at least $60 \%$ of the cell population observed (100200 cells/microscope field) exhibit an immediate step-down photophobic response.

We have previously reported that Na-salt addition to cells in $\mathrm{Cl}^{-}$containing buffers causes significant enhancement of the duration of the step-down photophobic response (Doughty et al. 1980). The enhancement is dependent upon $\mathrm{K}^{+}$concentration (Doughty et al. 1980) and the anion of the sodium salt. The results of a series of sodium salt additions are summarized in Fig. 1. In chloride-containing buffers, $\mathrm{NaCl}(1-16 \mathrm{mM})$ addition effects a 2.5 to 3 -fold enhancement of the duration of the responses if the buffers contain only $1 \mathrm{mM} \mathrm{K}^{+}$but only a 1.5 to 2 -fold enhancement of the buffers contain $5 \mathrm{mM} \mathrm{K}^{+}$. A similar pattern is observed for cells in the sulfate-containing buffers with large enhancement being observed with $8 \mathrm{mM} \mathrm{NaCl}$ addition in the presence of $1 \mathrm{mM} \mathrm{K}^{+}$and little effect with $5 \mathrm{mM} \mathrm{K}^{+}$ present. The enhancement is dependent upon $\mathrm{NaCl}$ concentration (not shown): The results for addition of $8 \mathrm{mM}$ $\mathrm{NaCl}$ are given in Fig. 1. Other sodium salts have different effects, however. Addition of sodium acetate significantly alters the motility of the cells in the presence of $1 \mathrm{mM} \mathrm{K}^{+}$ (see below) but has little effect on motility or step down response duration in the presence of $5 \mathrm{mM} \mathrm{K}^{+}$(acetate tested over the range of $1-16 \mathrm{mM}$ ). However, in the sulfate containing buffers, acetate addition causes enhancement of the response duration. A similar set of results was obtained for sodium propionate addition except that little alteration in motility was observed at either $\mathrm{K}^{+}$concentration. The propionate salt addition enhances the step-down photophobic response. Sodium nitrate $(1-16 \mathrm{mM})$ was also found to enhance the step-down responses of cells in chloride containing buffers (not shown). Sodium sulfate addition ( $>4 \mathrm{mM}$ ) was tested in the presence of $5 \mathrm{mM} \mathrm{K}{ }^{+}$and reduced the responses of cells in chloride-containing buffers but not the sulfate containing buffers.

As noted above, cell motility is altered by the addition of acetate to cells in chloride buffers containing $1 \mathrm{mM} \mathrm{K}^{+}$. Sodium acetate addition $(2-16 \mathrm{mM})$ caused significant reduction in progressive motility of the cells. The cells tended to aggregate in small groups $(10-20$ cells) and rapidly moved to the edges of the depression slides. Photobehavior analysis was thus not routinely possible. The clumping response was only weak in the presence of $5 \mathrm{mM} \mathrm{K}^{+}$(and chloride anions) and not apparent in the sulfate buffers. Propionate $(8$ or $16 \mathrm{mM}$ ) had a weak, but qualitatively similar effect to acetate only on cells in $1 \mathrm{mM} \mathrm{K} \mathrm{K}^{+}$and chloride anions. The acetate (or propionate)-induced motility change could, however, be reproducibly suppressed by short $(5-10 \mathrm{~s})$ exposure of the cells to $2-4 \mathrm{~W} \cdot \mathrm{m}^{-2}$ red light. After reduction of the red light to below $2 \mathrm{~W} \cdot \mathrm{m}^{-2}$, the clumping response slowly reappears. If the acetate response is supressed by red light, cells will show a step-down response to blue light removal that is $2-3$-fold longer than in the absence of $8 \mathrm{mM}$ acetate.

In most of our studies, we have routinely exposed the cells to a single period of blue light $(60 \mathrm{~s})$, the step-down response recorded on blue light removal and the cells discarded. In some solutions the cells can be re-exposed to blue light several times and show a step-down response, and return to forward swimming each time. Such sample stability is not observed for cells suspended in any of the culture media we have used (Doughty and Diehn 1983) since cell aggregation behavior appears rapidly (see acetate effect above and Robbins 1952; Colombetti and Diehn 1975). For cells in the chloride containing buffers, the duration of the step-down photophobic responses remains constant after each trial (Fig. 2a). This response constancy after repeated. testing has been observed in the presence of $\mathrm{Na}^{+}, \mathrm{K}^{+}$, $\mathrm{NH}_{4}{ }^{+}, \mathrm{Ca}^{2+}$ and $\mathrm{Mg}^{2+}$ additions (as chloride salts) and over a wide range of fluence rates $\left(1-320 \mathrm{~mW} \cdot \mathrm{m}^{-2}\right)$ for the blue light (unpublished results and see Doughty et al. 

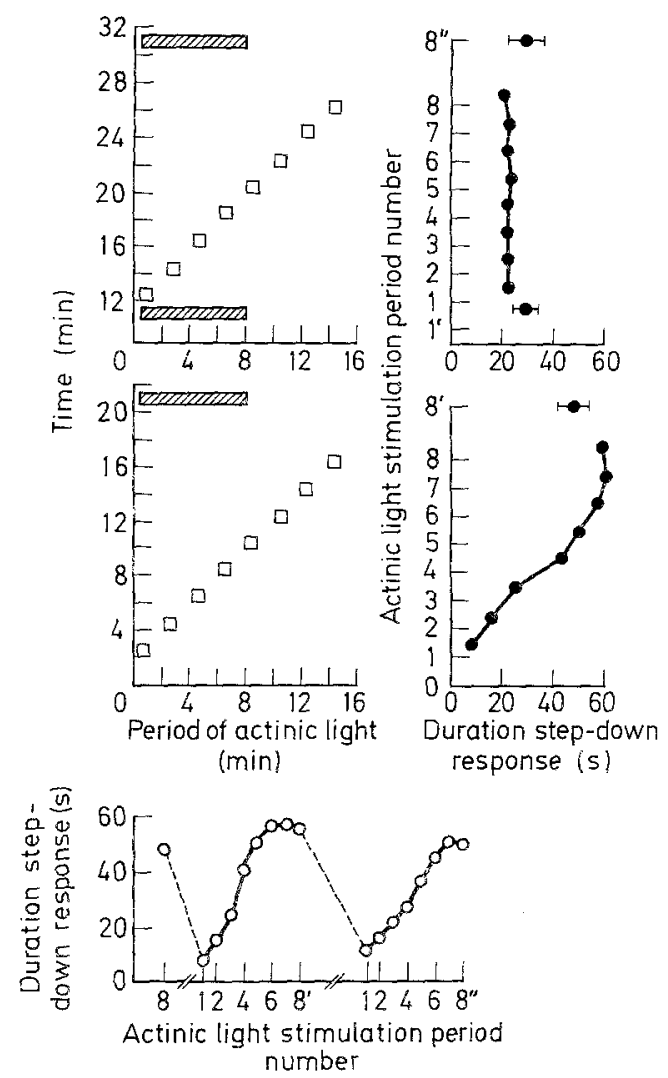

Fig. 2 a-c. Magnitude of the step-down photophobic responses of Euglena in response to sequential stimulation episodes in either chloride or sulfate anion containing buffers. Celis adapted to low $\mathrm{K}^{+}(1 \mathrm{mM}), \mathrm{Cl}^{-}$buffers (a) or to low $\mathrm{K}^{+}(1 \mathrm{mM}), \mathrm{SO}_{4}^{2-}$ buffers (b, c). Buffers at $\mathrm{pH} 7.1$ and containing $\mathrm{Ca}^{2+}$ and $\mathrm{Mg}^{2+}$ (see methods). Graphs $\mathbf{a}, \mathbf{b}$ show details of the periods of actinic stimulation of the cells and the duration of the subsequent responses on light removal. At bottom of Fig. are details of repeated sequences, with intermediate resting periods, in the $\mathrm{SO}_{4}^{2-}$-adapted cells

1980). After exposure to $40 \mathrm{~mW} \cdot \mathrm{m}^{-2}$ blue light for 6 or $8 \mathrm{~min}$ (instead of $60 \mathrm{~s}$ ), cells in chloride buffers show the same response as for a $60 \mathrm{~s}$ illumination period (Fig. $2 \mathrm{a}$ ). In contrast, cells in the sulfate containing buffers, while showing a short response to the first test, show a longer response to the second, an even longer response to a third test and so on (Fig. 2b). The cells were tested at the same light fluence rate and on the same time base as cells in chloride containing buffers and in all cases, the cells had resumed forward swimming before the next blue light exposure. Cells in the sulfate containing buffers also show a long response if illuminated with blue light continuously for 6 or $8 \mathrm{~min}$ prior to blue light removal to elicit the response. The long response duration appears to be the sum of the response observed after a sequence of 6 or 8 short illumination periods delivered at 2 min intervals. If the cells are left under red light for $10-$ $15 \mathrm{~min}$, the response to the next short blue illumination period is short and the response summation effect can be repeated (Fig. 2c). The response summation observed for sulfate-adapted cells in the presence of $1 \mathrm{mM} \mathrm{K}^{+}$would appear to be anion related since addition of $\mathrm{NaCl}$ to these cells, in a concentration-dependent manner, results in loss of the summation effect (Fig. 3a). The same relative effect can be achieved with addition of choline chloride (Fig. $3 \mathrm{~b}$ ).

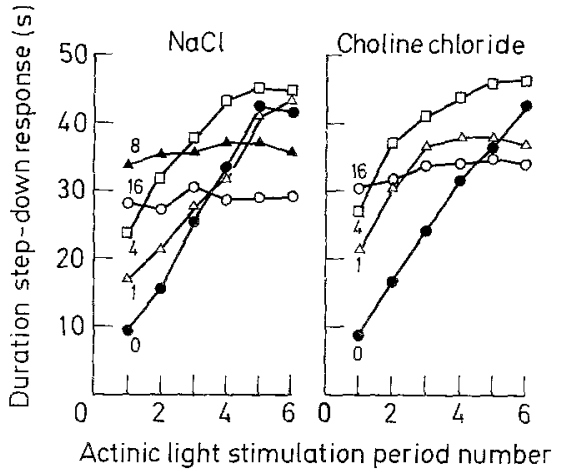

Fig. 3a, b. Effect of sodium chloride (a) and choline chloride (b) on step-down photophobic response summation for $\mathrm{SO}_{4}^{2-}$ adapted cells. Salts added, at the concentrations given, in $\mathrm{mM}$, to cell suspensions $1-2 \mathrm{~min}$ prior to the first exposure to actinic light. Details of cell preparation and time base of actinic stimulation as in Fig. 2

\section{Discussion}

The magnitude of the step-down photophobic response of Euglena is influenced both by cations (Colombetti et al. 1982; Doughty and Diehn 1983) and anions. In this paper we show that the cells appear to require chloride or sulfate anions for motility. Sulfate is present in most culture media, as a designated required ingredient, at 0.05 to $5 \mathrm{mM}$ concentrations (Kempner 1982).

Our studies collectively show the importance of ions in the selection of buffered solutions (adaptation buffers) for the study of Euglena photobehavior in a non-nutrient medium. In view of the influence of anions on the sensitivity of the step-down photophobic response to cations (and vice versa), the importance of adequate washing of the cells free of culture medium is self-evident. Bloomington media (Starr 1964) contains at least $12 \mathrm{mM}$ acetate. In addition, some types of "chemosensory" behavior of Euglena are light sensitive. While we have not observed direct responses to cations or anions of a type that resemble the step-down photophobic response, certain chemical conditions can have significant effects on cell motility. Very high concentrations of salts have been reported to alter flageliar activity (Mikolajczyk 1973). Preferential movement of Euglena into certain solutions has also been reported. Frank (1904), in a study on "washed" Euglena (and Chlamydomonas) observed that no overt responses were given to salts, noted accumulation into capillaries containing lactic or citric acid but no accumulation to acetic, malic or butyric acids. Mainx (1927) notes weak accumulation responses into dilute $\mathrm{HCl}$ and weak responses to acetate. Aggregatory (accumulation) behavior has also been reported for acetic acid-acetate mixtures (Bowne and Bowne 1967) and weak acid conditions (Robbins 1952). The acetate response observed in the present study, as with several other aggregatory responses of Euglena (Wager 1911; Robbins 1952; Colombetti and Diehn 1978 ) is influenced by light and thus may not be due to acetate directly. The light-induced suppression suggests a link to oxygen evolution (Colombetti and Diehn 1978). By whatever mechanism, the net result of the chemically induced behavior can be to alter the step-down photophobic responses. Significant effects of several organic acids (acetate, propionate and butyrate) on the photo behavior of Chlamydomonas have also been reported (Stahl and Meyer 1963). 
The sulfate substitution experiments show that with the removal of chloride anions, the cells need a longer exposure to light to achieve a comparable step-down response to cells with chloride present. Moreover, this longer response may be accomplished in instalments, suggesting that a stimulusgenerated reaction is cycled differently in the presence of sulfate compared to chloride. This point to an involvement of anions in the photosensory transduction chain at a point where stimulus integration is regulated.

Acknowledgement. This work was supported in part by grant No. PCM-79-05320 from the U.S. National Science Foundation to B. D.

\section{References}

Bowne SW, Bowne GD (1967) Taxis in Euglena. Exptl Cell Res $47: 545-553$

Colombetti G, Diehn B (1978) Chemosensory responses towards oxygen in Euglena gracilis. J Protozool 25:211-217

Colombetti G, Lenci F, Diehn B (1982) Responses (of Euglena) to photic, chemical and mechanical stimuli. In: Buetow DE (ed) The biology of Euglena, vol. iii. Academic Press, New York London, pp 169-195

Creutz C, Colombetti G, Diehn B (1978) Photophobic behavioral responses of Euglena in a light intensity gradient, and the kinetics of photoreceptor pigment interconversions. Photochem Photobiol 27:611-616

Diehn B (1973) Phototaxis and sensory transduction in Euglena. Science 181:1009-1010

Doughty MJ, Diehn B (1979) Photosensory transduction in the flagellated alga, Euglena gracilis. I. Action of divalent cations, $\mathrm{Ca}^{2+}$ antagonists and $\mathrm{Ca}^{2+}$ ionophore on motility and photobehavior. Biochim Biophys Acta 588:148-168
Doughty MJ, Diehn B (1983) Photosensory transduction in the flagellated alga, Euglena gracilis. IV. Long term effects of ions and $\mathrm{pH}$ on the expression of step-down photobehavior. Arch Microbiol 134:204-207

Doughty MJ, Grieser R, Diehn B (1980) Photosensory transduction in the flagellated alga, Euglena gracilis. II. Evidence that blue light effects alteration in $\mathrm{Na} / \mathrm{K}$ permeability of the photoreceptor membrane. Biochim Biophys Acta 602:10-23

Frank T (1904) Cultur and chemische Reizerscheinungen der Chlamydomonas tingens. Botanische Z 8:153-188

Greenblatt CL, Schiff JA (1959) A pheophytin-like pigment in dark adapted Euglena gracilis. J Protozool 6:23-28

Kempner ES (1982) Stimulation and inhibition of the metabolism and growth of Euglena gracilis. In: Buetow DE (ed) The biology of Euglena, vol iii. Academic Press, New York London, pp $197-252$

Mainx F (1927) Beiträge zur Morphologie und Physiologie der Eugleninen. II. Teil. Untersuchungen über die Ernährungs- und Reizphysiologie. Arch Protistenk 60:355-414

Mikolajczyk E (1973) Effect of some chemical factors on the movement in Euglena gracilis. Acta Protozool 12:133-142

Robbins WJ (1952) Patterns formed by motile Euglena gracilis var. bacillaris. Bull Torrey Bot Club 79:107-109

Shimmen T (1981) Quantitative studies on step-down photophobic responses of Euglena in an individual cell. Protoplasma $106: 37-48$

Stahl N, Meyer AM (1963) Experimental differentiation between phototaxis and motility in Chlamydomonas snowiae. Science $141: 1282-1284$

Starr RC (1964) The culture collection of algae at Indiana University. Am J Bot 51:1013-1044

Wager $H$ (1911) On the effect of gravity upon the movements and aggregation of Euglena viridis, Ehrb., and other microorganisms. Phil Trans Roy Soc Lond Ser B 201:333-390

Received November 3, 1983/Accepted March 7, 1984 